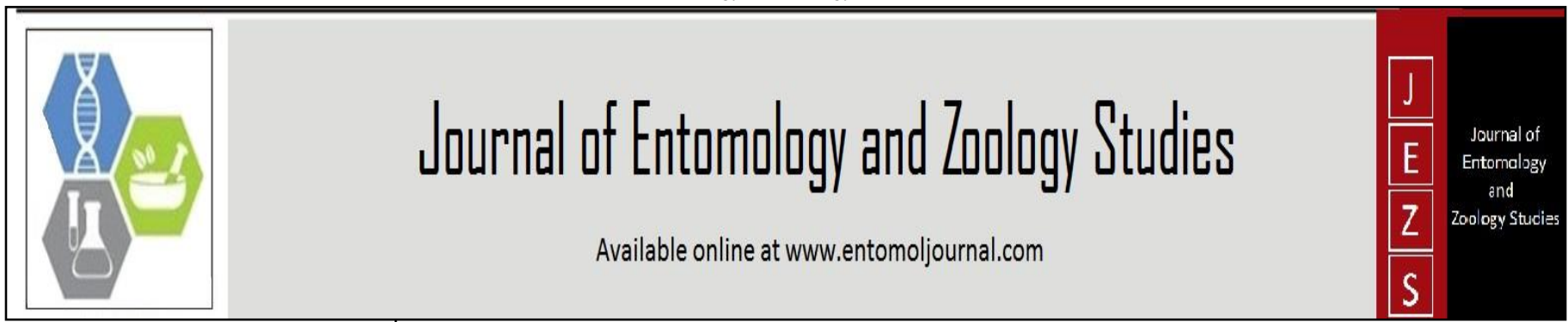

E-ISSN: 2320-7078

P-ISSN: 2349-6800

www.entomoljournal.com

JEZS 2021; 9(2): 182-184

(C) $2021 \mathrm{JEZS}$

Received: 22-01-2021

Accepted: 24-02-2021

Rohit Kumar Sharma

M.V.Sc. Scholar and Department

of Veterinary Surgery and

Radiology, College of Veterinary

and Animal Science, Bikaner,

Rajasthan, India

Manu Prabh Sharma

M.V.Sc. Scholar and Department

of Veterinary Surgery and

Radiology, College of Veterinary

and Animal Science, Bikaner,

Rajasthan, India

Dharampal

M.V.Sc. Scholar and Departmen of Veterinary Surgery and

Radiology, College of Veterinary and Animal Science, Bikaner,

Rajasthan, India

SK Jhirwal

Assistant Professor, Department of Veterinary Surgery and

Radiology, College of Veterinary and Animal Science, Bikaner,

Rajasthan, India
Corresponding Author: Rohit Kumar Sharma M.V.Sc. Scholar and Department of Veterinary Surgery and Radiology, College of Veterinary and Animal Science, Bikaner, Rajasthan, India

\section{Reposition of traumatic ocular proptosis through lateral canthotomy in a kitten}

\section{Rohit Kumar Sharma, Manu Prabh Sharma, Dharampal and SK Jhirwal}

DOI: https://doi.org/10.22271/j.ento.2021.v9.i2c.8478

Abstract

Present case reports a successful diagnosis and surgical management of traumatic unilateral proptosis in a one month old female kitten with lateral canthotomy under general anaesthesia. A Kitten presented in Veterinary clinical complex, Bikaner, with a history of dog fighting and clinical examination revealed moderate prolapse of left eye globe. Eye globe reposition as well as temporary tarsorrhaphy was done.

Keywords: kitten, traumatic ocular proptosis, lateral canthotomy, temporarory tarsorrhaphy

\section{Introduction}

The eye is undoubtedly the most uniquely crafted sensory organ of the vertebrate body (Don, 2013) ${ }^{[1]}$. Traumatic ocular proptosis is defined as forward displacement of the eye by a traumatic episode with entrapment of the eyelids behind the eye (Fossum, 2013) ${ }^{[2]}$. Severe trauma to head causes proptosis in cats and most common causes is fighting with larger breeds of same or other species like dogs which involve scruff of neck and head allows the eyes to pop forward. (Kumar et al., 2016) ${ }^{[3]}$. Traumatic proptosis can occur in any breed and in both dogs and cats (Gilger et al., 1995) ${ }^{[9]}$. In case of kittens fight with the larger cats tends to grab the kittens by the scruff of the neck and it predisposes to such affections (Kumar et al., 2016) [3]. Proptosis caused by traumatic episodes is a surgical emergency, and replacement of the globe should not be delayed unnecessarily (Fossum, 2013) ${ }^{[2]}$ and hence the present case was planned communication puts on a record of acute case of traumatic unilateral proptosis treated successfully by lateral canthotomy, reposition as well as temporary tarsorrhaphy technique in a mongrel kitten.

\section{Anamnesis and Clinical Finding}

A one month old female kitten was presented to Veterinary clinical complex, Bikaner with the history of dog fighting (Fig:1). Clinical examination revealed protruded left eye ball without fracture of skull. The menace reflex was negative while pupillary reflex revealed positive. According to clinical examination, replacement of eye ball was decided and canthotomy was performed under general anaesthesia to reduce further complication.

\section{Anaesthesia and surgical procedure}

General anaesthesia according to Tranquilli et al., (2013) ${ }^{[8]}$ were used to unconscious the animal with appropriate dose calculated after measuring the body weight $(0.2 \mathrm{Kg})$ of pug

Following drugs were used as balanced anaesthesia for required unconscious state :

\begin{tabular}{|c|c|c|c|}
\hline Name of drug & Purpose & $\begin{array}{c}\text { Dose-rate } \\
(\mathbf{m g} / \mathbf{k g})\end{array}$ & $\begin{array}{c}\text { Calculated } \\
\text { dose }(\mathbf{m l})\end{array}$ \\
\hline Atropine sulphate $(1 \mathrm{mg} / \mathrm{ml})$ & Anticholinergic agent & 0.044 & 0.01 \\
\hline Xylazine $(20 \mathrm{mg} / \mathrm{ml})$ & $\begin{array}{c}\text { Preanaesthetic, Sedative, } \\
\text { muscle relaxant }\end{array}$ & 0.2 & 0.05 \\
\hline Ketamine $(50 \mathrm{mg} / \mathrm{ml})$ & General anaesthesia & 15 & 0.06 \\
\hline
\end{tabular}

After unconsciousness of kitten, protruded eyeball was cleaned gently by $0.9 \%$ saline solution. Eye ball was lubricated gently by neomycin ointment and replacing in its orbit. 
The eye ball was replaced in its orbit successfully without affecting the other structures of eye. Lateral Canthotomy was performed as per need during treatment. Temporary tarsorraphy (Fig:2) was performed to retain the eye ball in orbit.

\section{Post operative care}

After replacement of eyeball following drugs were used in different manner :

\begin{tabular}{|c|c|c|c|}
\hline Name of drug & Purpose & $\begin{array}{c}\text { Route of } \\
\text { administration }\end{array}$ & Dose rate \\
\hline Dexamethasone \& Gentamicin & $\begin{array}{l}\text { To prevent secondary uveitis and } \\
\text { ocular infection }\end{array}$ & Subconjuctivally & $\begin{array}{c}2.2 \mathrm{mg} \& 20 \mathrm{mg}, \text { respectively } \\
\text { (single injection) }\end{array}$ \\
\hline Moxifloxacin & To prevent secondary infection & Topically in eye & 3 drops thrice a day for 7 days \\
\hline Flurbiprofen & Anti-inflammatory and analgesic & Topically in eyes & 2 drops twice a day for 5 days \\
\hline Carboxy methyl cellulose $(0.5 \%)$ & Artificial tears to prevent KCS & Topically in eye & 2 drops twice a day for 7 days \\
\hline Ceftriaxone & Systemic antibiotic & Intramuscular & $15 \mathrm{mg} / \mathrm{Kg}$, O.D. for 3 days \\
\hline B-complex (Tribivet) & Supportive & Intramuscular & $2 \mathrm{ml}$ total dose \\
\hline
\end{tabular}
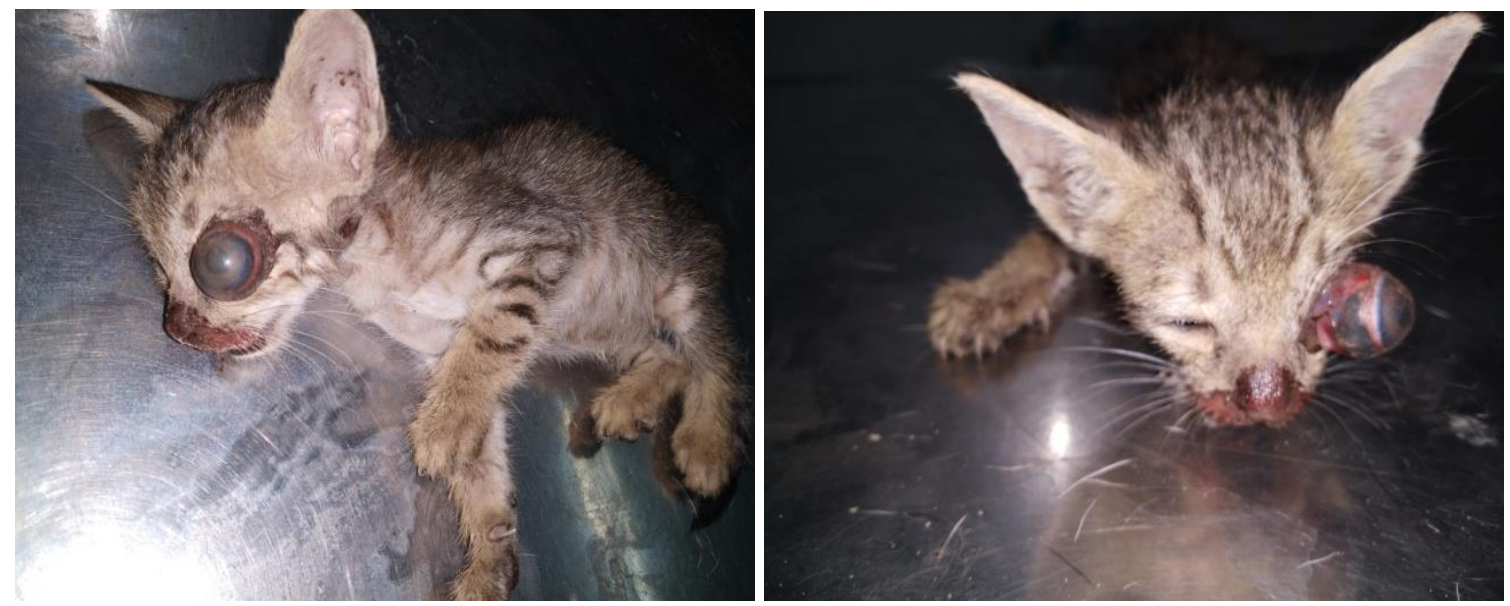

Fig 1: Photograph showing proptosed eyeball

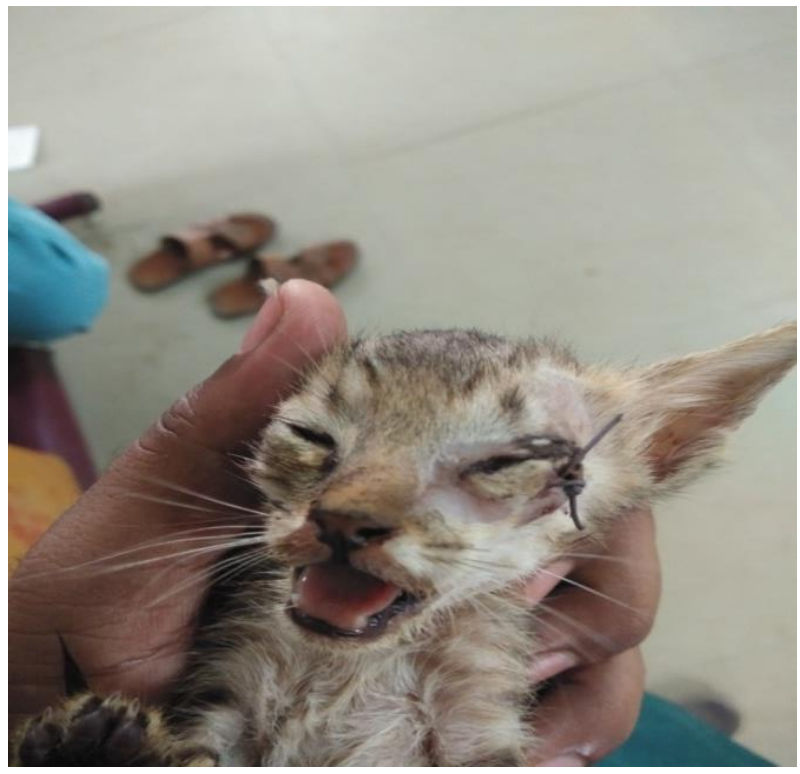

Fig 2: Photograph showing tarsorraphy in given case

\section{Results and Discussion}

Animal was completely recovered after a week of surgery without any further complication. Keratitis sicca (KCS) and optic nerve atrophy are the common sequel to proptosis which were not reported in this study since one month (Stephen, 2013 ${ }^{[6]}$. The ocular emergencies like proptosis can be treated with enucleation or replacement with tarsorraphy depending on the viability of extra-ocular tissue and eye (Mandell, 2005) ${ }^{[4]}$. In present case the extra-ocular musculature was enough to hinder the replacement of globe behind the lids with lateral canthotomy. Ofri (2008) ${ }^{[5]}$ opined presence of PLR reflex to be the important sign for canthotomy. Persian cats are more prone to traumatic proptoses, due to their flatter facial structure and shallow eye sockets, the condition can occur in any breed of cat. On ultrasonograhy, retina is an acute detachment is thin and highly echogenic, but with time, retinal membrane becomes thicker and moves to center of the vitreas to form a funnel shaped configuration (Spaulding, 2008) ${ }^{[7]}$.

Conclusion of study: Traumatic proptosis in small animals needed immediate surgical intervention and lateral canthotomy under general anaesthesia can be a successful surgical technique for management of traumatic proptosis in kitten and in this case minimum complications were observed.

\section{References}

1. Don A. Samuelson, Edited by Gelatt, K. N. (Fifth Ed.). Essentials of veterinary ophthalmology. John Wiley \& Sons 2013;1:39

2. Fossum TW. Fourth edition. Small Animal Surgery Textbook-E-Book. Elsevier Health Sciences, 2013, 318.

3. Kumar A, Rohi R, Pawar P, Kumar P. anagement of Traumatic Ocular Proptosis in Cat 2016.

4. Mandell DC. Ophthalmic emergencies. Clinical Tech. Sm. Anim. Pract 2005;15:94-100.

5. Ofri R. Differential diagnosis and treatment of blindness. Scientific proceedings: Companion animals programme. European veterinary conference, Voorjaarsdagen, 
Netherland 2008, 1.

6. Stephen I. Bistner, edited by: Slatter, D. H. (Second Ed.). Textbook of small animal surgery. W.B. Saunders company. 2, 288

7. Spaulding K. Eye and orbit. In: Atlas of Small Animal Ultrasonography. Penninck, D. And Marc-Andre d' Anjou (Eds.), Blackwell Publishing, USA 2008, 72-73.

8. Tranquilli WJ, Thurmon JC, Grimm KA. (Eds.). Lumb and Jones' veterinary anesthesia and analgesia. John Wiley \& Sons 2013.

9. Gilger BC, Hamilton HL, Wilkie DA, Van Der Woerdt A, McLaughlin SA, Whitley RD. Traumatic ocular proptoses in dogs and cats: 84 cases (1980-1993). Journal of the American Veterinary Medical Association. 1995; 206(8):1186-1190. 